\title{
Influence of Project Fund Mobilization Strategy on Implementation of Energy Access Projects in Underserved Counties in Kenya
}

\author{
Evans Kituzi Avedi \\ P.O. Box 9520 City Square, ODEL Campus \\ University of Nairobi, Nairobi, 00200, Kenya. \\ Dr. Angeline Sabina Mulwa \\ P.O. Box 30197 GPO, ODEL Campus \\ University of Nairobi, Nairobi, 00100, Kenya. \\ Prof. Dorothy Ndunge Kyalo \\ P.O. Box 30197 GPO, ODEL Campus \\ University of Nairobi, Nairobi, 00100, Kenya.
}

\begin{abstract}
The purpose of this articlewas to establish the extent to which project fund mobilization influence the implementation of energy access projects in underserved counties in Kenya. Data was collected from the respondents through questionnaires, interview guides and observationschedules. The coefficient of determination $R^{2}$ was 0.148 and it depicted that project fund mobilization explained $14.8 \%$ of variations in implementation of energy access projects in underserved counties in Kenya. The remaining $85.2 \%$ of variations in implementation of energy access projects in underserved counties remained unexplained and were explained by other variables other than project fund mobilization that were not captured in this model.The overall $F$ statistic of $F=17.239(p<0.05)$ was statistically significant at $P=0.000<0.05$ hence was suitable to measure project fund mobilization. This was an indication of a statistical relationship between project fund mobilization and implementation of energy access projects in the Kenya.
\end{abstract}

Keywords: Access to Energy, Project Fund Mobilization, Project Implementation, RuralElectrification, Underserved Counties

\section{Introduction}

Project Fund Mobilization is a financial strategy commonly used by organizations to raise capital to cover project costs before work begins on a project or prior to invoicing usually in the form of money, or other values such as effort or time, to finance a need, program and project, usually by an organization or company. This article provides a review of funding needs and financing mechanisms for energy access in general and off-grid electrification in particular to find whether the funding for these activities has been adequate, whether sufficient funding is likely to be available to meet the needs of universal energy access and whether innovative approaches can be used in funding. The study found out that in all successful cases the state has played an important role in funding infrastructure investments but many developing countries have neglected the energy access issue for a long time. International donor agencies have provided selective and limited support, while the innovative mechanisms are also unfriendly towards small-scale projects. Weak governance, limited organizational capacity and unfavourable policy environment militate against largescale mobilization of financial resources in the poorest countries of the world where energy access is a chronic problem. The challenge of mobilizing finance and ensuring its appropriate delivery and use remains a major issue and would require a coordinated effort of all relevant stakeholders (Kishoreand Gopal, 2013).

A project is considered successful if the project is delivered on time, on schedule and acceptable quality. Crawford and Bryce (2013) observed that a project is only successful if it comes on schedule, on budget, it achieves the deliverables originally set for it and it is accepted and used by the clients for whom the project was intended. Clark, (2009) on the other hand observed that different people measure project success in different ways at different times and that the satisfaction of the key project stakeholders, including the customer, was the overriding measure of project success, with stakeholders being satisfied if their quality related criteria were met.

Access to energy plays an indispensable role in enabling widespread socioeconomic development. The World Bank has acknowledged that in modern times no country has managed to substantially reduce poverty without greatly increasing the use of energy. Provision of access to energy services unlocks potential to enhance economic development, public health, education, water and sanitation, gender equality and a range of other factors affecting development goals. Energy access may enhance educational outcomes by providing improved studying conditions and better classroom 
technology, support public health and healthcare through reductions in respiratory illnesses, operation of basic medical equipment and provision of treatment at night and refrigeration of vaccines, medicines, and blood, spur economic development in several ways, including reduced household energy expenditure, enabling of enterprise development and increased connectivity and competitiveness and may also play a role in women's empowerment and gender equality across a range of mechanisms, including; time liberation, girls' education and women's health. Finally, the cumulative effect of energy access enables citizens to better their own socio-economic livelihoods, participate in an increasingly global market and ultimately contribute to economic development and prosperity domestically (Terri and Neha, 2015).

In Kenya and elsewhere, the energy sector is an important sector because it spurs economic growth (Stephen, 2014). In line with this, Kenya has developed Vision 2030 as one of its long-term development strategy. This strategy aims to improve the competitiveness of the country at a global scale. The strategy covers the period between 2008 and 2030 , and it focuses on transforming the country into becoming a manufacturing country and improving the quality of lives of the local people by making the country a middle-income nation. In this respect, the energy sector has so far been restructured in line with Sessional Paper No.4 of 2004 and the Energy Act No.12 of 2006.Previous studies indicate that economic growth is determined to some extent by the level of energy consumed in an economy. Accordingly, the Vision 2030 identified energy as an enabler of its social economic pillar. The government thereby committed to providing reliable, affordable and sustainable energy to all people in the country.

Today, 1.3 billion people still lack access to electricity, while the global electricity demand is growing almost twice as fast as the total energy. The United Nations (UN) has established access to affordable, reliable, sustainable and modern energy services for everyone as one of its Sustainable Development Goals (SDGs) to be reached by 2030 (IEA, 2014).The United Nations Secretary-General's initiative on Sustainable Energy for All (SE4All), launched in 2011 and based on multi-stakeholder approach, brings together partnerships between various actors including governments, the private sector and civil society to achieve the vision of sustainable energy for all. Ensuring access to energy to the underserved counties in Kenya wouldthus greatly and rapidly transform lives and livelihoods of people from the perspective of improvement in health, equity and empowerment of women, income-generating activities, education and environmental sustainability. Based on this background, this article therefore focused on the influence of project fund mobilization strategy on the implementation of energy access projects in selected underserved counties in Kenya.

\subsection{Statement of the Problem}

In sub-Saharan Africa, only 290 million out of 915 million people have access to electricity and the total number without access is rising. Nearly $80 \%$ of those lacking access to electricity across sub-Saharan Africa are in rural areas, an important distinction when considering appropriate energy access strategies and technical solutions (IEA, 2014). Kenya like any other developing country is not an exception in facing an energy problem. In Kenya only $46 \%$ of the population has access to electricity (2015) which means most of the population rely on traditional fuels for energy such as firewood, charcoal, kerosene. The total number of un - electrified households is 1.2 million in the 14 underserved counties in Kenya (Republic of Kenya, 2013). These underserved counties are West Pokot, Turkana, Marsabit, Samburu, Isiolo, Mandera, Wajir, Garissa, Tana River, Lamu, Kilifi, Kwale, Taita Taveta and Narok. Beside accounting for 72 per cent of the country's total land area and 20 percent of the country's population, access to energy in these counties is still very low compared to other counties in Kenya. Failures of completion of energy access projects within time, quality and budget in underserved counties has resulted in these areas remaining economically underdeveloped. The implementation of rural electricity programs has been a challenge to the government with only $36 \%$ of the rural population having access to electricity.

Previous studies have mainly focused on identifying factors affecting rural electrification with most researchers focusing on the role of Governments in driving rural electrification but very few have examined on the combination of legislative frameworks, funding mechanisms, institutional arrangements and co-ordination mechanisms, which work together to support the implementation of access to energy strategies and policies (Maithani and Gupta, 2015). In energy access projects, various key players in energy sector are set up with each player having a distinct role to ensure they deliver project objectives. These energy stakeholders work within a mix of skills and judgment and their differences manifest while exercising their skills and judgement during project implementation which further leads to huge disparities in time, cost and quality overruns during project implementation.

The under served counties of Kenya present profound infra structuredeficits, including lack of accessto roads, electricity, water and socialservices. Many cultures in marginalizedareas were historically nomadic, based on pastoralistlifestyles, and with low population densities. There is also significant insecurity incertainareas, giving riseto substantialnumbers o fdisplacedpersons and livelihood adaptations tha tfur ther undermine economic prosperity (Republic of Kenya, 2013). Due to the specific challenges posed by low population density, low energy demand and undeveloped rural economies, there is need for strategies that require special financing conditions, design and 
construction standards specifically formulated to address rural power-supply characteristics, and a project control mechanism that involved coordination and sequencing of the relevant projects so that losses arising from gaps between strategies and implementation are mitigated.

At the moment, the national government is implementing a solar PV electrification program for all public schools and other institutions in some parts of the country especially the remote ones. While this will enable the government to digitize most of the schools, it will also enable it to distribute renewable energy to those parts of the country (Government of Kenya, 2011). A number of studies that focus their attention on challenges of rural electrification in different parts of the world have been conducted over the years. Most of those studies indicate that for the country to supply electricity to rural areas, it would need to combine both on and off-grid electricity.

The current article study area has not been adequately studied in developing countries especially in underserved counties in Kenya. The influence of project fund mobilization strategy on implementation of energy access projects in underserved counties in Kenya therefore remains unknown. It is evident that there is need to have solid project fund mobilization strategies both individually and collectively. Based on this information and the many challenges of rural electrification that affect implementation of energy access projects encounter, there is need for further investigation on the influence of project fund mobilization strategy on implementation of energy access projects. Therefore, it is against this background that this article sought to focus on the influence of project fund mobilization strategy on implementation of energy access projects in underserved counties in Kenya.

\subsection{Objective of the Study}

The objective of the study was to establish the extent to which project fund mobilization influence the implementation of rural energy access projects in underserved counties in Kenya,

\subsection{Hypothesis of the Study}

The following hypothesis was tested:

i) $\mathrm{H}_{0}$ : Project fund mobilization does not significantly influence the implementation of rural energy access projects in underserved counties in Kenya.

ii) $\mathrm{H}_{1}$ : Project fund mobilization significantly influences the implementation of rural energy access projects in underserved counties in Kenya.

Project fund mobilization was thus considered a function of three possible strategies; attracting private investments, leverage funding and attracting impact investors

\section{Literature Review}

Financing electricity access for the poor is a major challenge, and even more so for the poor in Least Developed Countries. The International Energy Agency (2011) estimates that about US $\$ 48$ billion per year from 2010 throughout 2030 (nearly US\$ 1 trillion) is needed to meet the UN target, of which $90 \%$ is for electricity access. Actual investment in energy access is much smaller. In 2009 total investment in energy access was only US $\$ 9$ billion. Concerning future investments, the IEA estimates that under the new policy scenario, the expected investment on electricity access in the coming years amounts to US \$13 billion per year combining all financial resources (aid, public funds, and private investment), which equates to about a quarter of the amount required. This leaves a funding gap of US\$35 billion per year between 2010 and 2030 .

Looking across the entire power sector, it is estimated that Kenya will need a total of 18 - 23 billion USD by 2020 to achieve its targets in the power sector. Of this, Kenya has secured an estimated 3 to 5.5 billion USD, leaving a gap of $14-18$ billion USD in financing (Power Africa, 2017). This financing estimate includes all generation projects in the pipeline, including those expected to be completed post-2020 and on-grid connections for $70-80 \%$ of the population. Off-grid solutions present a lower capital expenditure intensive alternative for these more costly-to-connect households and Kenya Power operational improvements to reduce losses and improve system stability.

The Government of Kenya has acknowledged that achieving universal access to electricity in rural areas will require mobilizing many forces. Thus, a wide range of ownership structures will be permitted to operate rural electrification schemes. According to a report by Power Africa, (2017), projects led by the private sector, communities and Government will be encouraged to apply for capital subsidies to establish operations to provide rural electricity service. In addition, a range of private sector participation models (including concession, dealership and leasing arrangements) will be eligible.

These project sponsors will play a significant role in the development of rural electrification in Kenya. The emphasis on demand-driven service coverage also highlights the critical role communities will play in the development of rural electrification under the Government's new approach. 
Community support and desire for a given rural electrification scheme will be essential to ensuring the sustainability of a project. Project sponsors will be required to comply with certain qualifications, detailed in the rural electrification authority operational manual. Financial viability of electric distribution utilities is governed by the balance of costs and revenues generated from sales of energy and the cost of providing service. Due to lower population density, often lower income, and concurrently lower specific energy consumption for rural communities, rural distribution systems realize far lower revenue per kilometer of rural distribution line than their urban counterparts. Moreover, Zhang and Kumar, (2011) observed that, rural distribution service providers are also faced with higher operating expenses per household or commercial consumer served, given their lower energy density. Additionally, rural electric service providers recruit management and staff resources from communities that often have fewer trained engineers, accountants, financial specialists, and customer service specialists due to lower levels of professional and practical skills training.

Funding processes are important in the implementation of energy projects in the country (Njoki, 2013). There is no doubt that in the absence of effective funding processes, projects of whatever nature may not succeed. Macharia and Ngugi (2014) claim that funding processes within public sector are normally hampered by contractors with insufficient funds to fund their projects. Any funding process should consider the cost of construction materials, labor and equipments used during the implementation of a project (Otieno and Graca, (2010). Ven though contractors ought to have their own money to fund part of the project before they receive full funding from the government, funding processes that are not clear and effective may be a big challenge to public sector in the country.

In any funding process, measures should be put in place to ensure that the available fund can be relied upon (Esty and Christoy, 2002). Efforts should be made to ensure that project would not end up into debts, risks should be shared, and all sources of fund should be identified right at the start of project. This is not exceptional because concerted effort should be made to ensure that project will run to the end once started. Otherwise, there would be no need to start a project when it is expected that it would fail at some point (Daube and Alfen, 2008). Accordingly, funding structures should be established and the necessary mechanisms put in place to ensure that nothing would go wrong during the implementation process.

To overcome these challenges, the following strategies have been identified: attracting private investors into the energy sector through efficient funding processes, introducing commercial capital investment at lower interest rates, pursuing efficient business models, and establishing funding programs that would be sustainable. Private sector-led economic growth, fueled by private investment, increases economic opportunity, enhances access to public and private services, and reduces poverty (Power Africa, 2017). USAID's history of partnering with the private sector shows that partnerships are most effective when they have deep links between business strategies and development objectives creating intrinsic sustainability.

The context for financing global development has evolved dramatically over the past decade. According to Mardirosian, (2010) private capital now accounts for about 90 percent of financial flows to developing countries, due to growing private sector recognition of the financial and social benefits of investing in the developing world and governments' expanded efforts to diversify their economies and access capital for social investment. Increased investor interest in developing economies represents a watershed opportunity for governments and development agencies to mobilize the necessary resources to deliver development impact on the order of magnitude required by the Sustainable Development Goals.

The USAID is uniquely positioned to increase private resources towards development with its far-reaching global footprint. This is in accordance with Power Africa, (2017) report that indicates that the agency also has a deep understanding of the country and energy sector context, including relationships with key stakeholders, and a broad set of tools that can specifically address the riskreturn profile; grants, technical assistance, guarantees, partnerships, and convening power. These attributes also position USAID well as other development organizations, such as development finance institutions (DFIs) who may operate only in later stages or in more established markets. USAID addresses risk and transaction costs, provides support that builds a pipeline of investments for DFIs and the private sector, and draws on deep technical expertise in key sectors (agriculture, water, health, energy, and education) and extensive relationships across the public and private sectors. USAID's Office of Private Capital and Microenterprise aims to leverage private capital and expertise on an agency-wide basis to improve development and increase the funds available, while also transitioning developing countries to freer, more transparent, and more stable market economies. Impact Investors by launching a government-backed power sector bond, linked to a Sovereign Power Sector Modernization Package with specific reform covenants for example the process of accelerating land acquisition, establishing a clear revenue model for KETRACO and Geothermal Development Company, with the capital raised used to pay Government of Kenya obligations to scale on-grid distribution and creating a facility for social impact investors linked to off-grid electrification target delivery (Power Africa, 2017). 
If implemented fully, these solutions can close most of the total financing gap by 2020. In addition, the solutions can also contribute to a long-term sustainable reduction in the customer tariff rate by $6-12 \%$, largely by reducing the fuel surcharge that currently comes from heavy fuel oil generators. These solutions can also reduce the Government of Kenya obligation to finance the power sector by up to $60 \%$, largely by bringing in more private capital (Power Africa, 2017).

The ability to leverage grant funding and secure private investment from investors is in fact one of the critical drivers of HPS's growth. From taking the business model from blueprint to validation stage, grants by Shell Foundation proved to be a key factor in India's energy access funding strategy. Shell Foundation provided a series of targeted grants which were conditional upon initiating changes in the business. In all, Shell provided a total of \$2.3 million to HPS between 2008 -11 (Koh., Karmachandani., and Katz., 2012). Sadeque, and Soni (2014) in a related study found out that the grant funding from Shell helped in creating the core components required for scale for example, in designing its business strategy, recruiting senior managers, building awareness about the HPS brand, funding R\&D activities to decrease capex for plants, for developing the smart meter and importantly leveraging Shell's global expertise to dramatically improved safety conditions at its operational sites, thereby reducing low probability, high-impact risks. It is therefore evident that grant agencies and impact investors have clear measurable and reliable indicators for assessing scalability of enterprises, which is seldom seen in government driven programmes.

Strengthen public utilities by financing operational transformation and capital expenditure execution improvement at KenGen and Kenya Power to match performance to best-in-class, supported by impact-based financing (including vendor financing) and Generating new equity capital from sale of shares in some of KenGen's current operating assets, which KenGen can then allocate to new generation projects. Public priorities for the electricity sector have shifted in recent years as rapid technological development enables a cleaner, more affordable, reliable, and safe electric system (Binz, and Ron, 2015). Private companies are offering customers more choices and control over their electricity, through energy efficient products and services, demand management, self-generation like rooftop solar, smart electric vehicle chargers and on-site storage. At the same time, the role of cost-effective utility-scale wind and solar is growing.

New technologies and new grid configurations can increasingly deliver on traditional goals like affordability, reliability, clean energy, safety, and universal service. Because of these new market forces and new options, the institutions governing the electricity system must too evolve. How utilities and their regulators and boards keep up with changing customer values and technologies depends on the utility ownership model. For most of electricity consumers, private companies (investor-owned utilities, or IOUs) provide electricity service (Malkin, and Centolella, 2014). The public utilities commissions that regulate IOUs can use performance-based regulation (sometimes called results or outcomes-based regulation) to align IOU incentives with customer value. Performance-based regulation of IOUs uses financial rewards and penalties for achievement of public policy outcomes in the electricity sector. It is thus against these arguments that the current article attempted to study the influence of project fund mobilization on the implementation of energy access projects in underserved counties in Kenya.

\subsection{Theoretical Framework}

This article is anchored on stakeholder theory

\subsubsection{Stakeholder Theory}

Stakeholder theory was first described by Dr. Edward Freeman, a professor at the University of Virginia, in 1983 and originally published in 1984 in his landmark book, Strategic Management: A Stakeholder Approach. It suggests that shareholders are merely one of many stakeholders in a company. The stakeholder ecosystem, this theory says, involves anyone invested and involved in, or affected by, the company: employees, environmentalists near the company's plants, vendors, governmental agencies, and more. Freeman's theory suggests that a company's real success lies in satisfying all its stakeholders, not just those who might profit from its stock. Stakeholder theory is a specific approach to recognizing and dealing with stakeholders. The way in which organizations approach stakeholder engagement, the tools and techniques used to engage stakeholders, and, at a philosophical level, the purpose of the organization are built on which view of stakeholders is accepted by the organization's governing body (Kirsi, 2010). The basic idea of stakeholder theory is that organizations have relationships with many constituent groups and that it can engender and maintain the support of these groups by considering and balancing their relevant interests.

Kirsi (2010) further noted four premises of the stakeholder theory that; corporations have relationships with many constituent groups (stakeholders) that affect or are affected by its decisions, the theory is also concerned with the nature of these relationships in terms of both processes and outcomes for the firm and its stakeholders, that the interests of all (legitimate) stakeholders have intrinsic value and not one set of interests is assumed to dominate others, and finally the theory focuses on managerial decision making. 
Based on the argument of instrument of power of this theory, a company using stakeholder approach will have increased organizational performance in terms of economics and other criteria (Hasan and Kami, 2010).

\subsection{Conceptual Framework For The Study}

Independent Variable Project Fund Mobilization Strategy

Dependent Variable

\section{Attracting Private Investments}

- Scale up financing in the power sector

- Private sector-led economic growth

- Encourage blended project financing

- Partnership with the private sector

- diversify their economies and access capital for social investment

\section{Leverage Funding}

- Secure private investment from investors

- Grant funding

- Strengthen public utilities

\section{Attract Impact Investors}

- Government-backed power sector bond

- Creating a facility for social impact investors

- Establishing a clear revenue model

- Accelerating land acquisition

Figure 1: Conceptual Framework for the Influence of Project Fund Mobilization Strategy on Implementation of Energy Access Projects.

\section{Research Methodology}

The study on this article used pragmatism paradigm.Mixed method research looks at many approaches for collecting and analyzing data rather than subscribing to only one way either qualitative or quantitative. Migiro and Magangi (2011) states that mixed methods research encourages researchers to use multiple approaches to collecting and analyzing data within a single study, recognizing the limitations of using a single method. In this article, quantitative data was collected using structured questionnaires whilst qualitative data was collected using interview schedules and observation guide.

The unit of analysis was households, commercial centers, schools and hospitals. The projects were in 14 counties under equalization fund and spread out in the 14 counties in underserved counties in Kenya. These underserved counties are West Pokot, Turkana, Marsabit, Samburu, Isiolo, Mandera, Wajir, Garissa, Tana River, Lamu, Kilifi, Kwale, Taita Taveta and Narok. The target population was 5,604 residents drawn from the six service territories based on county allocations derived from scale of challenge (un-electrified population and community facilities), poverty index and population density to achieve greatest impact with limited resources, deliver services where the need is the largest, consider additional costs due to low population density and consider principles of equity such that all counties should benefit in a similar manner. Such a division allows economies of scale in procurement and elicits private sector contractors to be present in these undeserved counties over a long term.

A sample size of 373 respondents was selected from a target population of 5,604 residents in areas where rural electrification has been implemented in underserved counties in Kenya through stratified sampling and purposive sampling techniques. Data was collected from the respondents through questionnaires, interviews and observation. 
Data was triangulated through comparison of qualitative data received from structured questionnaires for clients with qualitative in- depth interviews for site engineers and observation guide by the researcher. Qualitative data was analyzed by checking data, developing codes, identifying themes and patterns and then summarizing the data and linking them to objectives and hypothesis. Quantitative data was further analyzed by employing descriptive and inferential statistics generated. Descriptive results were presented as percentages, arithmetic means and standard deviation while inferential statistics were obtained using Pearson's Product Moment correlation and from simple and multiple regression while F-test was used to test hypotheses.

This article paper produced both quantitative and qualitative data to explain the influence of project fund mobilization on implementation of energy access exhaustively. Once data collection activity was over, the researcher edited and also tackled the issue of blank responses, coded, categorized and keyed in the data into SPSS program for actual analysis to be done. This exercise was done to check for completeness of that data was collected using the questionnaire. This data was then subjected to Normality test which was first checked by using plots, by significance tests of comparing the sample distribution to a normal distribution and Kolmogorov- Smirnov test statistics (KS-test) and Shapiro-Wilk test which were carried out to provide inferential statistics on normality using the SPSS. Multicollinearity test was done using Variance of Inflation factor (VIF) whose values were between 1 and 4 within all variables. According to Marquardt (1970), VIF values greater than 10 indicate severe multicollinearity. In the current study, there was no multicollinearity. To ensure validity of the models developed in this study, multiple regression assumption tests were performed which included the normality and multicollinearity. Correlation analysis was also undertaken. Data analysis techniques employed were simple and multiple regression.

The researcher further performed descriptive analysis to measure central and dispersion tendencies of variables using mean, standard deviation, frequencies and percentages. Study variables were also tested through inferential analysis which was used to test the hypotheses which was further used to generalize the findings from the sample studied. F-test was carried out to assess the significance of the whole equation or to test best of fit. $\mathrm{R}^{2}$ which refers to coefficient of determinations was also used to show how successful the best of fit was in explaining the variation of the data. In addition to the $\mathrm{R}^{2}$ test, the test of the slope using $\mathrm{t}$ - statistic was performed to assess the significance level of the individual regression coefficient of each study variable.

Statistical Package for Social Sciences (SPSS) IBM Version 23 tool was used to generate descriptive and inferential statistics. Level of significance alpha was set at 0.05 and the confidence level at $95 \%$. Measures of central tendencies were used on finite data values. This was done so that data was normally distributed and clustered around the average value. Based on the standard deviation from the average data was then measured to check if it had strong or weak tendency. Qualitative data obtained from the questionnaires, in-depth interviews and observation were analyzed separately. Qualitative data analysis is working with data, organizing them, breaking them into manageable units, coding and synthesizing them and searching for patterns. The aim for searching for the patterns was to be able to explain or identify the influencing links from the data collected. Thus, qualitative data process involved analyzing transcripts, identifying themes within those data and gathering together examples of those themes from the text (Burnard and Chadwick, 2008).

Data triangulation was done so as to strengthen the validity and reliability of the data collected. Data was therefore collected from different participants and different sites of the setting. Data obtained was therefore cross-checked for consistency of specific and factual data items s recorded in the data collection instruments. In the current study, data was analyzed through comparison of qualitative data received from structured questionnaires for clients with qualitative in-depth interviews for site engineers and observation guide by the researcher. Further data obtained from the structured questionnaire was analyzed both descriptively and inferentially. The results were then corroborated with those from the structured in-depth interviews and observation guide.

To further analyze the data, Pearson's Product Moment correlation coefficient(r) and multiple linear regression models were utilized to analyze the influence. Pearson's Product Moment correlation coefficient(r) was used to describe the strength of relationship between the independent predictor variable and dependent variable. The test was carried out on a two-tail test since it allowed for either influence to the positive or negative direction while hypothesis testing was tested at $95 \%$ level of confidence and significance level of .0 .05 . Multiple regression analysis was used to analyze the influence of combined rural electrification expansion strategies on the implementation of energy access projects. The hypothesis with linear relationship was analyzed using simple regression analysis and Pearson's Product Moment Correlation used for interpretation of results. Together with simple graphics analysis, descriptive statistics form the basis of virtually every quantitative analysis to data. 
Correlation analysis to establish the relationship between the independent and dependent variables was employed. Pearson's product moment correlation coefficient (r) was used to test the relationship between the independent and dependent variables. Interpretation of the results for the linear relationships of this study was based on; for a weak correlation $\mathrm{r}$ ranging from +0.10 to +0.29 ; moderate correlation between +0.30 to +0.49 ; while strong correlation from +0.50 to +1.0 (Shirley, D., Stanley, W., \& Daniel, C., (2005). That is, the empirical models were used to portray the connection between the study variables which ranged from correlation test using Pearson correlation coefficient and regression models to test for degree of significance of the association

\section{Findings And Discussions}

The goal of the study was to establish the extent to which project fund mobilization influence the implementation of rural energy access projects in underserved counties in Kenya. Questionnaires were administered to 373 respondents. Out of these 302 of them came back filled while 71 were either incomplete or not at all filled. This represented a response rate of $81 \%$ which is generally representative enough for analysis and generalization of results to the population. The results are in tandem with studies by Babbie (2003) that states that a return rate of $50 \%$ is sufficient to rely on the questionnaire for purposes of analysis. Further he stated that a return rate of $60 \%$ was considered to be good and $70 \%$ was assumed to be excellent for data analysis.

\subsection{Overall Descriptive Analysis on Project Fund Mobilization}

Project Fund Mobilization was considered in terms of Attracting Private Investments, Leverage Funding and Attract Impact Investors. The mean and standard deviation of these factors as manifested in rural energy access projects is as shown in Table 1:

Table 1: Mean and Standard Deviation of Project Fund Mobilization

\begin{tabular}{lccc}
\hline Project fund mobilization & N & Mean (M) & $\begin{array}{c}\text { Standard } \\
\text { Deviation }\end{array}$ \\
\hline Attracting Private Investments & 302 & 3.45 & 0.798 \\
Leverage Funding & 302 & 2.9 & 0.800 \\
Attract Impact Investors & 302 & 3.50 & 0.778 \\
\hline Composite mean & & $\mathbf{3 . 2 8}$ & \\
\hline
\end{tabular}

The results from Table 1 show that Attracting Private Investments contribute to implementation of energy access projects to a moderate extent $(\mathrm{M}=3.45, \mathrm{SD}=0.798)$, Leverage Funding to a neutral extent $(\mathrm{M}=2.9, \mathrm{SD}=0.800)$ and Attract Impact Investors to a great extent $(\mathrm{M}=3.50, \mathrm{SD}=0.778)$. This implies attracting impact investors is a vital consideration when energy access projects are being implemented in rural areas in Kenya.

\subsection{Correlation Between Project Fund Mobilizationand Implementation Of Energy Access Projects}

To establish the direction and magnitude of the relationship between implementation of energy access projects and project fund mobilization a correlation analysis was conducted. Project fund mobilization is a composite of three indicators; attracting private investments, leverage funding and attract impact investors. The results of the correlation analysis are presented in Table 2:

Table 2: Correlation between Project Fund Mobilizationand Implementation of Energy Access Projects

\begin{tabular}{llccc}
\hline & & $\begin{array}{c}\text { Attracting } \\
\text { Private } \\
\text { Investments }\end{array}$ & $\begin{array}{c}\text { Leverage } \\
\text { Funding }\end{array}$ & $\begin{array}{c}\text { Attract } \\
\text { Impact } \\
\text { Investors }\end{array}$ \\
\hline Implementation of Energy Access & $\begin{array}{l}\text { Pearson } \\
\text { Correlation }\end{array}$ & $.209^{*}$ & $.349^{*}$ & $.165^{*}$ \\
& Sig. (2-tailed) & 0.000 & 0.000 & 0.004 \\
& N & 302 & 302 & 302 \\
\hline *. Correlation is significant at the 0.05 level (2-tailed) & & & \\
\hline
\end{tabular}

From the results of Table 2, all the indicators of Project fund mobilization are significantly positively correlated with implementation of energy access projects. In terms of magnitude, leverage funding is the highest with $\mathrm{r}=0.349$ followed by attracting private investments at $r=0.209$ and then attract impact investors at $r=0.165$. As correlation however does not mean causality; therein a regression analysis was conducted to verify if there is a statistical relationship between the indicators of project fund mobilization and implementation of energy access projects. 


\subsection{Inferential Analysis of Influence of Project Fund Mobilization onimplementation of Rural Energy Access Projects in Underserved Counties in Kenya.}

The following hypothesis was tested using simple regression model to satisfy the objective.

i) $\mathrm{H}_{0}$ : Project fund mobilization does not significantly influence the implementation of rural energy access projects in underserved counties in Kenya.

ii) $\mathrm{H}_{1}$ : Project fund mobilization significantly influences the implementation of rural energy access projects in underserved counties in Kenya.

The hypothesis was tested using the functional specification and simple linear regression analytical model as follows:

Functional specification: $\mathrm{y}=\mathrm{f}\left(\mathrm{Xi}, \varepsilon_{\mathrm{i}}\right)$ where $\mathrm{Xi}$ are the independent variables and $\varepsilon_{\mathrm{i}}$ is the error term and $\mathrm{i}=1,2,3,4$

Analytical model: $y=\beta_{\mathrm{oi}}+\beta_{\mathrm{i}} X_{\mathrm{i}}+\varepsilon_{\mathrm{i}}$ where $\beta_{\mathrm{oi}}$ is the constant of regression of $\mathrm{y}$ on $\mathrm{X}_{\mathrm{i}}$ and $\beta_{\mathrm{i}}$ is the coefficient of Xi Implementation of rural energy access projects $=\mathrm{f}$ (project fund mobilization)

$\mathrm{Y}=\mathrm{f}\left(\mathrm{X}_{1}, \boldsymbol{\varepsilon}\right)$

$\mathrm{Y}=\beta_{\mathrm{o}}+\beta_{1} \mathrm{X}_{1+\varepsilon} \boldsymbol{\varepsilon}$; Where

$\mathrm{Y}=$ Implementation of rural energy access projects; $\mathrm{X}_{1}=$ Project fund mobilization; $\beta_{\mathrm{o}}=$ Constant term; $\beta_{1}=$ Beta

Coefficient; $\boldsymbol{\varepsilon}=$ Error term

The results are as presented in Table 3 .

Table 3: Project Fund Mobilizationand Implementation of Energy Access Projects

\begin{tabular}{lcccc}
\hline \multicolumn{4}{c}{ Model Summary } \\
\hline Model & $\mathrm{R}$ & $\mathrm{R}$ square & Adjusted R & $\begin{array}{c}\text { Std. Error of the } \\
\text { Estimate }\end{array}$ \\
& & & Square & 3.526
\end{tabular}

Predictors: (Constant) AP, LF, AI

\section{ANOVA}

Model

Sum of squares

Regression

$642.9 \quad 3$

Residual

3704.6

3

Total

4347.5

301
Mean Square

214.304

12.431

Dependent Variable: Implementation of Energy Access Projects

Predictors: (Constant) AP, LF, AI

\section{Coefficients}

\begin{tabular}{|c|c|c|c|c|c|}
\hline \multirow[t]{2}{*}{ Model } & \multicolumn{2}{|c|}{$\begin{array}{l}\text { Unstandardized } \\
\text { Coefficients }\end{array}$} & \multirow{2}{*}{$\begin{array}{c}\text { Standardized } \\
\text { Coefficients } \\
\text { Beta }\end{array}$} & \multirow[b]{2}{*}{$\mathrm{t}$} & \multirow[b]{2}{*}{ Sig. } \\
\hline & B & Std. Error & & & \\
\hline (Constant) & 15.137 & 2.139 & & 7.077 & 0.000 \\
\hline $\begin{array}{l}\text { Attracting Private } \\
\text { Investments }\end{array}$ & 0.307 & 0.125 & 0.135 & 2.461 & 0.014 \\
\hline $\begin{array}{l}\text { Leverage Funding } \\
\text { Attract Impact }\end{array}$ & 0.813 & 0.15 & 0.303 & 5.434 & 0.000 \\
\hline Investors & 0.193 & 0.125 & 0.085 & 1.553 & 0.122 \\
\hline
\end{tabular}

Dependent Variable: Implementation of Energy Access Projects

The model was further subjected to other goodness of best fit tests of coefficient of determination and test of the slope $(\beta)$ as shown from the results in Table 3 . The assessment of the test of coefficient of determination showed $R^{2}=0.148$ and $\mathrm{r}=0.385$, an indicator that generally project fund mobilization is moderately correlated with implementation of energy access projects. The $\mathrm{R}^{2}=0.148$ was the coefficient of determination for this model and it depicted that project fund mobilization explained $14.8 \%$ of variations in implementation of energy access projects in underserved counties in Kenya. The remaining $85.2 \%$ of variations in implementation of energy access projects in underserved counties remained unexplained and were explained by other variables other than project fund mobilization that were not captured in this model. In terms of individual indicators of project fund mobilization, both attracting private investments and leverage funding are statistically significant at $5 \%$ level of significance, since for attracting private investments $\mathrm{p}=0.014<0.05$ and for leverage funding $\mathrm{p}=0.0<0.05$. 
Further, the $\beta$ coefficient test degree of change in the outcome variable for every one-unit of change in the predictor variable of every individual predictor variable on the independent variable was carried out.The results as per Table 3 revealed that all the indicators apart from attracting impact investors 0.085 , is not statistically significant at $10 \%$ $(\mathrm{p}=0.122)$ level of significance or less. Attracting private investments beta coefficient of 0.135 is statistically significant at $10 \%(\mathrm{p}=0.014)$ level of significance implying there was a positive significant relationship between attracting private investments and implementation of energy access projects. The coefficient of leverage funding 0.303 is also statistically significant at $5 \%(\mathrm{p}=0.0 .000)$ level of significance implying also that leverage funding had a very strong positive statistically significant influence on implementation of energy access projects. In terms of the comparison the variable leverage funding influenced more implementation of access projects more than attracting private investments.

The overall $\mathrm{F}$ statistic of $\mathrm{F}=17.239(\mathrm{p}<0.05)$ is statistically significant since $\mathrm{P}=0.000<0.05$ hence the model at $\mathrm{P}=0.000<0.05$ was suitable to measure project fund mobilization. This was an indication that there was a statistical relationship between project fund mobilization and implementation of rural energy access projects in the Kenya. Hence, the study rejected the null hypothesis which states that: $\mathrm{H}_{0}$ : Project fund mobilization does not significantly influence the implementation of rural energy access projects in underserved counties in Kenya. This conclusion made by the study meant that that project fund mobilization has a significant influence on the implementation of rural energy access projects in underserved counties in Kenya.

Using the statistical findings in Table 3, the regression model arising from this analysis was as follows:

$\mathrm{Y}=15.137+0.307 \mathrm{AP}+0.813 \mathrm{LF}+0.193 \mathrm{AI}$

Where; Y = Implementation of Energy Access Projects; AP = Attracting Private Investments; LF = Leverage Funding; $\mathrm{AI}=$ Attract Impact Investors

The findings on the influence of project fund mobilization strategy on the implementation of energy access projects were in concurrence with studies by Otieno and Graca, (2010) who contends that key in public infrastructure project is its funding processes and without which can lead to the project facing financial difficulties. The Government of Kenya has acknowledged that achieving universal access to electricity in rural areas will require mobilizing many forces. This study is further supported by Tomas and Sanchez, (2013) who noted the poor and especially the rural poor cannot make the capital investment to meet their electricity needs; the magnitude of the financial gap for energy access for the poor is immense; and that no clear solution to fill such a gap has appeared so far. The results of the current article findings found out that all the indicators of project fund mobilization are significantly positively correlated with implementation of energy access projects. In terms of magnitude, Leverage Funding is the highest with $r=0.349$ followed by attracting private Investments at $r=0.209$ and then Attract Impact Investors at $r=0.165$. However, attracting impact investors was a vital consideration when energy access projects are being implemented in rural areas in Kenya. These results are supported by a study by Kaiser and Ahlemann, (2010) who argue that without a clear funding process in any public infrastructure implementation may lead to the project contractor applying poor materials and also leads to inefficient communication, unreliable suppliers, and late project deliveries.

\section{Conclusion And Recommendations}

This section presents the conclusions made in line with the objective and hypothesis of the article study. The research objective sought to establish the extent to which project fund mobilization influenced implementation of rural energy access projects in underserved counties in Kenya. Project fund mobilization was measured in terms of attracting private investments; leverage funding, attract impact investors and were based on literature review and included in the research instrument. Descriptive statistics showed that the dominant indicator was attracting impact investors, followed by attracting private investments and then leverage funding. This implies attracting impact investors is a vital consideration when energy access projects are being implemented in rural areas in Kenya. This could be explained by the following reasons as noted by the respondents: Inadequate funding, very few investors, Funding was not available, Fund disbursement was slow; there is need for more investors. Some were of the view that vices of corruption and bribery were a challenge in project fund mobilization, their sentiments were: poor distribution of funds, bribery of available funds, corruption, misuse of public funds, inadequate strategic and operational plans, accountability and transparency, political interference. The results from inferential statistics indicated that all the indicators of project fund mobilization are significantly positively correlated with implementation of energy access projects. In terms of magnitude, Leverage Funding is the highest with $r=0.349$ followed by Attracting Private Investments at $r=0.209$ and then Attract Impact Investors at $r=0.165$. The overall $F$ statistic of $F=17.239$ is statistically significant since $\mathrm{P}=0.000<0.05$. This was an indication that there existed a statistical relationship between project fund mobilization and implementation of rural energy access projects in the Kenya. 
It was therefore concluded that project fund mobilization strategy was faced with challenges that need to be addressed as majorly suggested by the respondents by having an increase in the levels of funding and an attraction of more investors to the sector so as to achieve full potential of implementation of energy access projects. Due to this, the null hypothesis was rejected therefore concluded that there was a positive influence of project fund mobilization on implementation of energy access projects in underserved counties in Kenya and there is a need to actively engage project funding institutions during strategy formulation.

The recommendations from the study findings was a creation of a favorable environment which can attract various levels of funding and more investors to the sector by subsidizing of consumer connections cost, domestic house wiring material cost and the unit cost of energy. The study further recommended that sufficient funds be allocated and timely disbursement for implementation of grid extension and generation projects in a coordinated manner. Providing access to credit or financing options could help rural households meet the upfront cost associated with electrification.

\section{References}

Babbie, E., (2003). Survey Research Methods. Belmont, California: Wadsworth Publishing Company.

Binz, R., \& Ron, L., (2015). How Renewable Energy Can Save Utilities Money: An Empirical Analysis of Project Cost, Performance, and Pricing Trends in the United States, Lawrence Berkeley National Laboratory, September. 2015.

Clark, K. B., (2009). Project scope and project performance: the effect of parts strategy and supplier involvement on product development. International Journal of Managementscience,35(10), 1247-1263.

Crawford, P., \& Bryce, P., (2013). Project monitoring and evaluation: a method for enhancing the efficiency and effectiveness of aid project implementation. International Journal of Project Management, 21(5), 363-373.

Daube, D., Vollrath, S., \&Alfen, H. W. (2008). A comparison of Project Finance and the Forfeiting Model as financing forms for PPP projects in Germany. International Journal of Project Management, 26, 376-287.

Esty, B. C., \&Christov, I., (2002). An overview of project finance - 2001 Update. Harvard Business School, N9-202105.

Hasan, F., \& Kami, M. I., (2010). The Performance Implications of Fit among Environment Strategy, Structure, Control System and Social Performance. International Journal Social and environmental accounting, 3(2) 117-142.

IEA., (2014). World Energy Investment Outlook Special Report 2014: International Energy Agency of the Organization of Economic Co-operation and Development (OECD), Paris.

Kirsi, A., (2010). Stakeholder Management in International Projects. Aolto University, doctoral dissertation series 2010/13.

Kishore, V., Jagu, D., \& Gopal, E., (2013). Technology Choices for Off-Grid Electrification. InRural Electrification Through Decentralized Off-grid Systems in Developing Countries, S.Bhattacharayya, Ed. Springer-Verlag: London, 2013; pp 39-74.

Koh, H., Karmachandani, A., \& Katz R., (2012). From Blueprint to Scale: The Case for Philanthropy in Impact Investing, Monitor Group.

Macharia, S.,\&Ngugi, K., (2014). Determinants of successful completion of power projects in Kenya Power and Lighting Company. International Journal of Social Sciences and Entrepreneurship, 1 (12), 570-580.

Maithani, P.C., \& Gupta, D., (2015). Achieving Universal Energy Access in India, New Delhi: SAGE.

Malkin, D., \&Centolella, P., (2014). Results-Based Regulation: A Modern Approach to Modernize the Grid Resources for IOU performance-based regulation.

Mardirosian, R. C., (2010). Infrastructure Development in the Shadow of Conflict: Aligning Incentives and Attracting Investment. In Global Projects Center, University of Stanford: 2010.

Migiro, S. O., \&Magangi, B. A. (2011). Mixed Methods: A Review of Literature and the Future of the New Research Paradigm. African Journal of Business Management, 5(10), 3757-3764. doi: 10.5897/AJBM09.082.

Njoki, M. N., (2013). The role of Project Management Information Systems towards the success of a Project: The case of Construction Projects in Nairobi Kenya. International Journal of Academic Research in Business and Social Sciences.HR MARS, Vol.3, No.9, ISSN: $2222-6990$

Otieno, K., O., Apida, M., Eric, O., N, Graca, A. (2010). Factors Influencing Fire Stations Response to Disasters: A case of Kenya. International Journal of Disaster Management and Fire Engineering. Vol. 3, Issue No.2, ISSN: $2221-6799$.

Power Africa, (2017). Development of Kenya's Power Sector 2015-2020. https://www.usaid.gov/sites/default/files/documents/1860/Kenya_Power_Sector_report.pdf 
Republic of Kenya, (2017). Kenya Off-Grid Solar Access Project for Underserved Counties: Resettlement plan Vol. 2. http://documents.worldbank.org/curated/en/194591490351167867/Annexes.

Republic of Kenya, (2013). Updated least cost power development plan study period: 2011-2031. http://www.renewableenergy.go.ke/downloads/studies/LCPDP-2011-2030-Study.pdf

Sadeque, Z., Rysankova, D., Elahi, R. \&Soni, R., (2014). Scaling Up Access to Electricity:The case of Bangladesh, Livewire, The World Bank.

Stephen, M. S. M., (2014). Determinants of Timely Completion of Projects in Kenya: A Case of Kenya Power and Lighting Company

Terri, W., Neha, R., Sean, E., Sadie, C., \& Tim, R., (2015). Policies to Spur Energy Access.: National Renewable Energy Laboratory.

Zhang, X., \& Kumar, A., (2011). Evaluating renewable-energy-based rural electrification program in western China: emerging problems and possible scenarios. Renewable and Sustainable Energy Reviews 15 (1), 773-779. 